\title{
Water Markets - Economic Instruments to Manage Scarcity
}

\author{
Henning Bjornlund
}

\author{
Centre for Regulation and Market Analysis, University of South Australia, North Terrace, \\ Adelaide SA 5001, Australia and University of Lethbridge, Alberta, Canada.
}
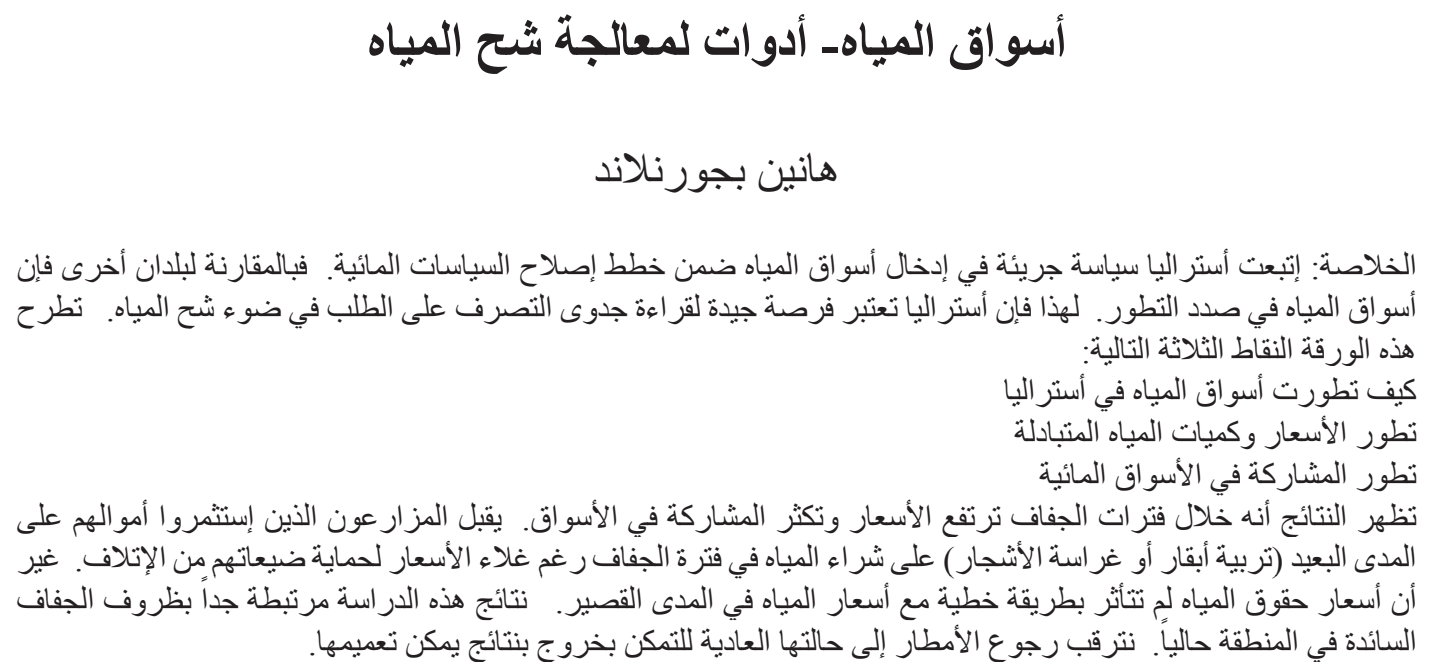

ABSTRACT: Australia has aggressively pursued water markets as an integral part of water policy reforms. Compared to most other countries, relatively active water markets have therefore emerged. Consequently, Australia provides an unique opportunity to study how markets have been introduced and adopted and their role in managing demand and scarcity. This paper discusses: a) how water markets have evolved in Australia, b) prices paid and volumes traded in water markets, and c) the increase in market participation. During periods of drought, scarcity is the main driver of price and market participation. Irrigators do not buy water in order to maximize their profits due to good commodity prices. Farmers with significant investments in long-term assets purchase water to protect their assets against long-term losses due to inadequate watering. This behavior drives prices to levels where no other agricultural users can compete. The price of water entitlements fluctuates with the price of water allocations, but irrigators do not capitalize scarcity-driven short-term increases in allocation prices into the price of entitlements. Once the region is out of this period of drought further research should be conducted to establish the water price/commodity price relationship during periods of more normal supply.

Keywords: Water trading, Australia, market drivers, demand management.

\section{Introduction}

Since the early 1990s, the use of economic instruments to manage demand for water within an environment of scarcity has been increasingly promoted by international organizations. Australia has aggressively implemented market policies since 1994. Compared to most other countries, markets in water allocations (the right to short term use of water) have developed to a high level of maturity, whereas markets for water entitlements (the long term right to access water) 
have been more subdued. Analyses of water market prices to establish the factors impacting irrigators' willingness to pay and accept prices are few and far between. This is due in part to the paucity of water pricing data (Brookshire et al., 2004), the thin markets in many areas, the private nature of price information and the relatively short time period during which active markets have existed. Thirteen years of pricing and market data are now available for water markets in the Goulburn-Murray Irrigation District (GMID) in Victoria, Australia, on the basis of which crosssectional and time series analysis can be conducted.

Australia provides an unique opportunity to analyze water market data to identify what factors influence market prices and markets' ability to manage scarcity. This paper first discusses the evolution of water markets in Australia. It then outlines the methods and data used for the analysis. The following four parts discuss the outcome of analyses of prices and volumes traded in the allocation and entitlement markets based on papers previously published by the author. The final two parts provide previously unpublished findings regarding the impact of allocation markets on water use and the increase in farm businesses' participation in water markets.

\section{The Evolution of Water Markets in Australia}

In Australia, markets for water entitlements and allocations first emerged formally in South Australia in 1983 without any direct legislative provisions. This was provoked by early scarcity, created by a moratorium on new licenses and a reduction in existing but unused or underused licenses in the 1970s. When demand started to increase from new high value users, such as horticulture and viticulture, in the early 1980 s, the pressure was on to create alternative means to provide water for these ventures. Trading in allocations was introduced in New South Wales (NSW) the same year, and in Victoria the first trial allocation markets were introduced in 1987. Markets for entitlements were introduced by legislation in both these states in 1989, but in Victoria the regulations controlling trading were not passed until September 1991 and the first trades were not registered until January 1992. Informal water trading was taking place earlier than this, during periods of severe scarcity, by allowing transfers between entitlements in the same ownership, through the purchase and amalgamation of irrigated land. In some instances water authorities allowed water bailiffs to redirect water between neighbors (Turall et al., 2005).

Water markets were made compulsory in all states as part of the new water policy reform initiated by the Council of Australia Governments (CoAG) in 1994. Initially, trading in both markets was thin (Turall et al., 2005; Bjornlund, 2003a). Irrigators soon became familiar with the allocation market, whereas the use of the entitlement market has, for a number of reasons, remained low (Bjornlund, 2004a). For a discussion of how irrigators have used markets to manage supply risk and the process of structural change see Bjornlund (2002, 2004b, 2006a).

As the use of the allocation market increased, irrigators demanded more efficient market mechanisms to allow them to purchase water instantly when factors of supply and demand changed. Consequently, in 1998, a weekly water exchange was introduced in the GMID to ease the administrative pressure on the authorities and to facilitate faster and cheaper transactions (Bjornlund, 2003b).

In 2003, CoAG reviewed the 1994 reform program and found that good progress was being made, but that the existing market mechanism still prevented water markets from achieving their most beneficial outcomes. In 2004, CoAG therefore introduced a new National Water Initiative. Among other things it aimed to improve the operation of water markets and the emergence of markets in more sophisticated derivative water products by providing: a) better specified and nationally compatible water entitlements, defined as shares of the available resource rather than in volumetric terms; and b) secure water entitlement registers. The policy process of evolving more efficient and sophisticated water markets is still ongoing and the ambitions of establishing derivative markets in order to achieve the potential efficiency gains experienced from such markets in other commodities are in their infancy (ACIL Tasman, 2003).

\section{Methods and Data}

The analyses in this paper are based on thirteen years of market data from the GMID. Data related to the price paid for water in the market for water allocations and in the market for water entitlements were collected. Allocation prices were obtained from Plan Right, the largest water broker in the district, for the period 1991-98 and from WaterMove, the water exchange that operates on a weekly basis, for the period 1998- 
2004. Entitlement prices were obtained from surveys conducted by the author for the period 1992-96 and from Plan Right for the period 1997-2004. Data related to volumes of water traded on a monthly basis were obtained from the records of Goulburn-Murray Water (GMW), the Authority that manages the GMID.

The data has been analyzed using time series analyses of mean monthly prices and monthly volumes traded, as well as by cross sectional regression and correlation analyses also using mean monthly prices and monthly volumes traded as dependent variables and measures of scarcity, commodity prices and macro-economic factors as independent variables. The objectives of these analyses were to identify: 1) trends in water prices and volumes traded; 2) factors determining irrigators' willingness to pay and accept prices for water; 3 ) factors determining volumes traded in the market; and 4) the relationship between prices paid in the allocation and entitlement markets. The outcome with respect to the allocation market has been published in Bjornlund and Rossini (2005a); the outcome with respect to the entitlement market in Bjornlund and Rossini (2006), and the comparison of the allocation and entitlement prices in Bjornlund and Rossini (2005b). The discussions in the next two sections are based on this literature and the reader is referred to these papers for a comprehensive discussion of the actual equations, statistical details, and full discussions of the outcomes. This paper will concentrate on discussing aspects of the analyses which assist our understanding of how water markets have been used as an economic instrument to manage water scarcity and how scarcity has driven prices and activities in water markets.

The last part of the paper draws on an analysis of the water entitlement and water trading registers, as well as water use data from the GMID, to establish how farm businesses have adopted water markets over the first 13 years of operation and how this relates to water scarcity. Increases in water trading based on volumes traded have previously been reported in papers such as Turall et al. (2005) and Bjornlund (2004b), but a proper analysis of the extent to which farm businesses have adopted water trading has not previously been conducted. To facilitate the most meaningful analysis, water entitlements were first consolidated into farm businesses. This was done by sorting the entitlement register by surname and address, and then consolidating all entitlements in the same ownership into one farm business. This process reduced the original number of 17,125 service numbers in the entitlement register to 14,384 farm businesses. Next, farm businesses without a tradable water entitlement were eliminated. This reduced the number of farm businesses to 10,011 . The trading registers were then merged with the entitlement register to identify which farm businesses participated in which kind of trading during each of the 13 irrigation seasons and identifying which farm business had participated in some kind of trading from the start of trading to the end of each season.

\section{Results and Discussion}

\section{The Market for Water Allocations - Factors Driving Market Prices}

Initial expectations were that the allocation market would allow irrigators to adjust to short-term fluctuations in supply and demand for water as well as in commodity prices. Analyses of prices and volumes traded in the allocation market suggest that the main driver of market activities and prices is scarcity, resulting in an annualized growth in allocation prices of 30.85\% (Bjornlund and Rossini, 2005a).

Most commodity prices have a significant but negative correlation with allocation prices. It is noteworthy that this is the case for dairy products since historically, in the GMID, the dairy industry has been the main high value water user and the main buyer of water allocations and entitlements. This suggests that increased allocation prices during the study period are not a result of irrigators buying additional water in pursuit of opportunities of increased profit due to higher commodity prices. In a way this could appear to be counterintuitive. However, it is also exactly what we expect the market to do - facilitate a reallocation of water during scarcity to minimize the negative impact of the drought - in this case to allow high value users to stay in business. The main concern of these businesses during this period of scarcity is to minimize their losses, which is the best possible economic outcome for them in the short term. Further research is needed to see how market prices react once the region is out of this period of extreme scarcity.

Hedonic analyses show no significant causal relationship between the price of dairy products and the price of water allocations. However, there is clear evidence that when the price of feed for dairy 
cattle rises, the willingness to pay for water to grow grass increases. This supports anecdotal evidence that, during periods of drought and when the price of water allocation is high, dairy farmers to some extent substitute buying water to grow grass with buying feed (Bjornlund, 2003b). It was also found that when seasonal allocations are low the price of allocations goes up The seasonal allocation is set by GMW as a percentage of entitlement at the beginning of each season depending on water availability in the reservoirs and is then revised fortnightly depending on inflows into the storages (that is dependent on precipitation in the catchment).

Seasonal allocations go down due to low precipitation in the catchments of the major reservoirs. This decreases the supply to irrigators and therefore increases demand in the allocation market, resulting in a higher willingness to pay for water allocations. Finally, it was found that as evaporation increases the price of water allocations go up. This is because more evaporation increases water use, as irrigators need to apply water not only to support plant growth but also to replace the loss of soil moisture due to evaporation. This in turn results in higher demand in allocation markets and higher market prices.

In conclusion, prices in the allocation market have been driven by scarcity rather than by commodity prices. Irrigators' willingness to pay is driven by their effort to reduce losses due to inadequate watering. When prices on the allocation market have increased to $\mathrm{A} \$ 500 / \mathrm{ML}$, this has been driven by horticultural farmers protecting their long-term investments in plantings, and at prices up to around $\mathrm{A} \$ 300 / \mathrm{ML}$ by dairy farmers protecting their long-term investments in dairy herd and milking equipment. If farmers are unable to feed dairy cattle they will be forced to sell at a time where the market is depressed and cattle prices are low. It also takes many years to build up a dairy herd to be productive. Further, if cattle are sold off, or sent out to pastures in areas not affected by drought, milking volumes will decrease, reducing farmers' ability to service their debt. In short, they pay more for water than is profitable in order to stay in business. There is anecdotal evidence of banks supporting this approach by lending money to farmer to buy water at loss-making prices. During this period of extreme scarcity due to drought and policy changes, the allocation market has played an important role in enabling high value water users to protect their assets and stay in business in the long term. In the short-term they have had to accept increasing allocation prices relative to commodity prices and therefore have experienced decreasing profits (Bjornlund, 2006b).

\section{The Market for Water Allocations - Factors Driving Market Activity}

Hedonic analyses using monthly volumes of water traded as the dependent variable also show that it is scarcity that drives market activity. This is true both immediately and as a delayed reaction. First, if evaporation is high during a given month, the level of trading is also high as irrigators need to apply more water to keep meeting plant requirements. Second, as the deficit between precipitation and evaporation accumulates over a three-month period, the volume of water traded increases. This deficit represents the volume of water that the irrigators have to apply to accommodate plant needs. This finding supports anecdotal evidence (Bjornlund, 2003b). Irrigators receive their seasonal allocation at the beginning of the season and there is no rule that they have to space their use of the water. They can use it all in the beginning of the season and then rely on buying water later in the season. It has therefore been reported that some irrigators do not buy when scarcity first sets in; initially they use the part of their allocation that they know they will need later in the season. This is especially the case if prices in the allocation market are high. They hope that prices will decrease so that they can buy cheaper later, that it will rain later in the season so that demand will decrease, or that inflows to the reservoirs in the catchments increase and allocations therefore go up eliminating the need to purchase water.

It was also found that during the months of January to March, which covers the hottest and driest part of the year, the volume of water traded is significantly higher than during any other period. This reflects that irrigators have different management responses to scarcity. Some risk-averse farmers, with the financial ability to buy water, purchase what they need for their planned crops based on the opening allocation, providing them with peace of mind during the season. Others are more risk-takers, or do not have the ability to pay for water at the beginning of the season. They 
postpone buying water until they have used up their seasonal allocation and then find that the crop still needs water. They do this in the hope that prices will be lower later in the season [this has historically proven to be the case during most seasons (Bjornlund, 2003b)] or that rains come early so that they do not need to buy water to finish their crops (Bjornlund, 2004c). Finally, it was found that as the price of allocations increase the volume of water traded decreases. This indicates that as scarcity drives prices up, irrigators buy smaller volumes to accommodate their cash flow; and in the hope that further purchases can be avoided due to rain or increased allocation, or that prices might go down again.

\section{The Market for Water Entitlements - Factors Influencing Price}

The activities in the entitlement market show less direct impact of seasonal scarcity caused by fluctuations in evaporation and rainfall. This is as expected, since the price of entitlements should reflect the long-term impact of scarcity rather than withinseason fluctuations. It was also found that the price increase over the study period has been only half that of water allocations, with an annualized increase of $15.41 \%$ (Bjornlund and Rossini, 2006). Reflecting scarcity, two main factors determine the price of water entitlements. First, the allocation level: since 1996 seasonal allocations have been drifting lower in response to scarcity due to drought and policies, such as water trading, increased environmental entitlements and capping of water use in the Murray-Darling Basin. As allocations have decreased, prices of water entitlements have increased in response to increased demand in the market as many irrigators wanted to offset lower seasonal allocations by purchasing more entitlements rather than buying more seasonal allocations (see also the discussion in the following section). In a sense this is illogical as lower allocations mean that the entitlements yield less allocation each season; something which should result in a lower willingness to pay. Second, as the price of allocations increases, so does the price of entitlements. This is supported by a comparison of the cyclical factors for allocation and entitlement prices (Bjornlund and Rossini, 2005b). The two cyclical factors are almost synchronized. However, when extreme scarcity during 2002/03 caused a substantial increase in allocation prices, irrigators did not capitalize this increase into the price of entitlements. It was also found that although the cyclical factors are almost perfectly synchronized, their magnitude is very different with the allocation factor being twice as high as the entitlement factor. This suggests that entitlement prices are far more stable than are allocation prices, and that irrigators do not capitalize extreme fluctuations in allocation prices into the entitlement price. Irrigators are aware when changes in allocation prices are due to short-term fluctuations in the underlying fundamentals rather than long-term factors.

\section{The Market for Water Entitlements - Factors Influencing Market Activity}

The analysis of factors influencing market activities in the entitlement market was not nearly as conclusive as the previously discussed analyses. The level of unexplained variability in volume traded was very high. However, some of the findings are of interest: 1) When the price of water entitlements increases, the volume traded declines. 2) When the price of water allocations increases, the volume of water traded in the entitlement market also increases. This supports clear anecdotal evidence that, while prices in the allocation market were low and water was readily available, there was a trend among many irrigators to rely on purchases of water allocations (Bjornlund, 2003b). However, since the price of water allocations has gone up and scarcity has caused increased competition in the allocation market, many irrigators have showed an increased interest in buying water entitlements to provide a greater level of certainty of supply during periods of scarcity. 3) As the price of dairy products increases, dairy farmers become more confident and therefore are willing to buy more water entitlements despite the fact that there is a negative correlation between the price of water allocation and the price of dairy products.

\section{The Impact of Allocation Markets on Total Water Use}

This section analyzes water use data and total volume of water traded on the allocation market. Table 1 shows how big a proportion of total water use was generated by the allocation market since 1995 in the two main supply systems of the GMID: the Murray and the Goulburn Systems. As can be seen from the table, the Murray System recently has had a higher allocation level than the Goulburn System. Irrigators 
Table 1. Relationship between seasonal allocations and extent of trade.

\begin{tabular}{|c|c|c|c|c|}
\hline \multirow{2}{*}{ Season } & \multicolumn{2}{|c|}{ Goulburn System } & \multicolumn{2}{|c|}{ Murray System } \\
\hline & Allocation $(\%)^{1}$ & $\%$ of trade $^{2}$ & Allocation $(\%)^{1}$ & $\%$ of trade ${ }^{2}$ \\
\hline 1995/96 & 150 & 7 & 200 & 3 \\
\hline 1996/97 & 200 & 4 & 200 & 3 \\
\hline $1997 / 98$ & 120 & 9 & 130 & 13 \\
\hline 1998/99 & 100 & 13 & 200 & 5 \\
\hline $1999 / 00$ & 100 & 14 & 200 & 8 \\
\hline 2000/01 & 100 & 16 & 200 & 2 \\
\hline 2001/02 & 100 & 18 & 200 & 5 \\
\hline $2002 / 03$ & 57 & 24 & 129 & 16 \\
\hline $2003 / 04$ & 100 & 16 & 100 & 18 \\
\hline $2004 / 05$ & 100 & 18 & 100 & 22 \\
\hline
\end{tabular}

Source: Goulburn-Murray Water's Records

${ }^{1}$ Maximum seasonal allocation.

${ }^{2}$ Total water trade for season as percentage of total water use.

in the GMID have a very high level of supply security. Their entitlements are designed to be delivered in full in 96 out of 100 years. In addition, irrigators in most years get access to additional water when the reservoirs contain more water than is needed for the current and next season. In many years allocations are well in excess of $100 \%$ of entitlement. However, this excess has declined considerably over the last 20 years from consistently being 200 percent or more to consistently being at $100 \%$ and in one season well below. This has caused scarcity among many irrigators because they have developed their properties to rely on the historically high allocations.

It is apparent from Table 1 that the allocation market has succeeded in transferring water among competing users in periods of scarcity. When allocations are at $200 \%$, trading accounts for only $8 \%$ or less of water use; this level of trade reflects irrigators buying water to benefit from good commodity prices or high demand for their commodities. As scarcity increases, trade accounts for a higher proportion of water use, up to about $20 \%$ with $100 \%$ allocations and as much as $24 \%$ when the allocation dropped to $57 \%$ in the Goulburn System (also the total volume traded that season was higher than during any other season). It is clear that trading in the Murray System did not accelerate until allocations in that system declined to close to $100 \%$, something that occurred for the first time in $1997 / 98$ and then consistently for the three seasons from 2002 to 2005. It is apparent from these data that the allocation market has had a significant impact on irrigators' ability to cope with scarcity, allowing high value producers with capital investments in plantings, herds and equipment to protect their investments and stay in business by paying low value producers not to use their water (Bjornlund 2004b,c; 2003a,b).

\section{Increase in Market Participation and Scarcity}

This section analyses how farm businesses in the GMID have adopted water markets and how this adoption rate has been influenced by scarcity. Figure 1 shows the proportion of farm businesses that participated in any kind of water trading during each season. That is, they bought or sold water in either the allocation or entitlement markets. The figure shows a significant increase in market participation over time. During the first six years, when allocations in both systems were in excess of $200 \%$ (except during $1995 / 96$ when it was only $150 \%$ in the Goulburn System) the participation rate mainly stayed below $10 \%$. The exceptions are that the participation rate: 1) peaked during $94 / 95$ as trading rules were relaxed and trading was introduced between irrigation district irrigators and private diverters; 2) remained high in the eastern part of the Goulburn System as the allocation dropped to $150 \%$; and 3 ) increased to about $30 \%$ in the western part of the Goulburn System. This last event happened because this area has the highest proportion of low-value broad acre cropping, grazing and mixed production farms with lower value water uses as well as large areas with significant soil degradation problems. This area therefore had the greatest potential 


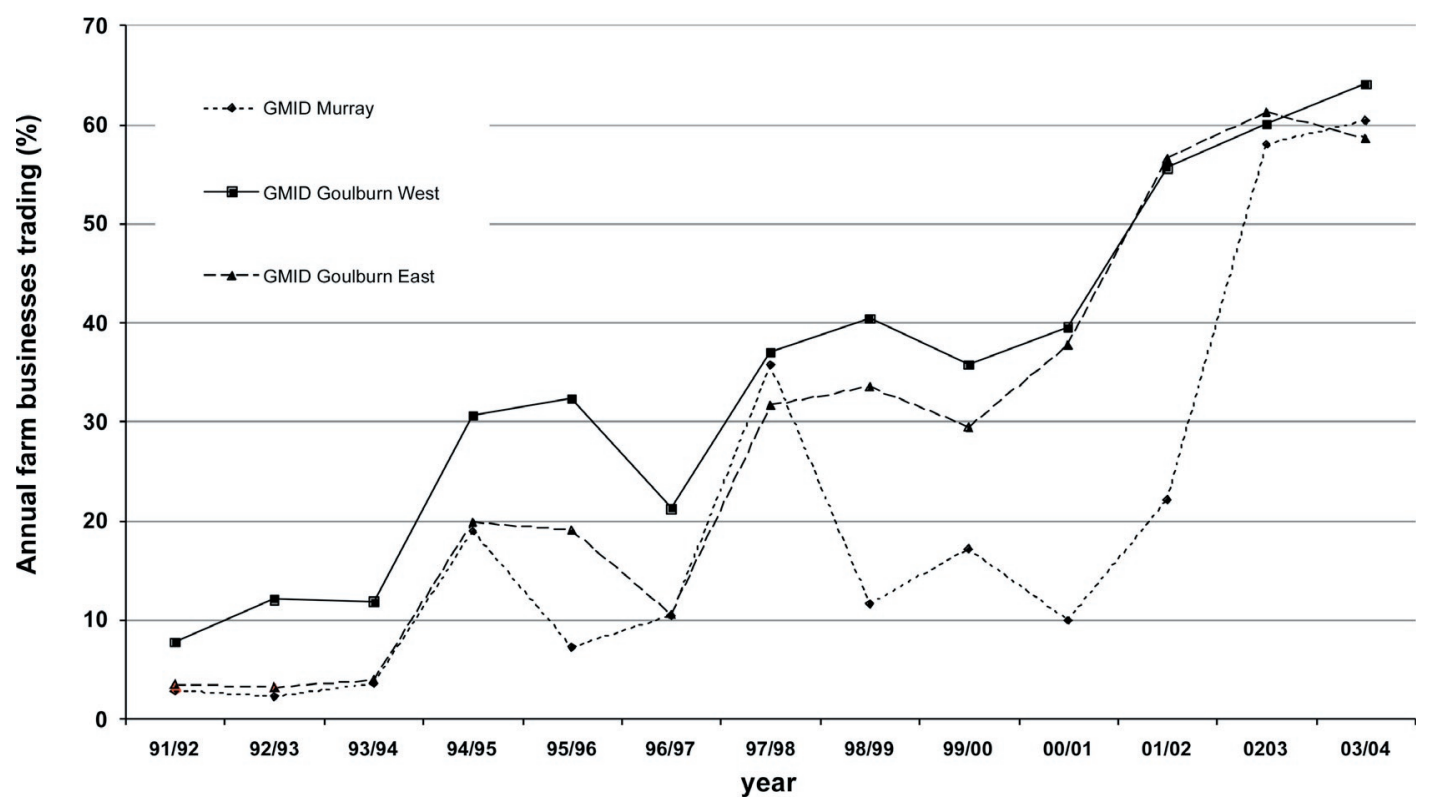

Figure 1. Percentage of farm businesses trading annually.

for beneficial trade-offs between irrigators with high and low value crops and productive and unproductive soils.

The level of market participation increased to almost $40 \%$ in both systems during $1997 / 98$ when allocations were low (Table 1). Following that year, allocations remained low in the Goulburn System, resulting in steadily increasing market participation. The allocation level in the Murray System returned to $200 \%$ and the participation rate declined to $10-20 \%$ until allocation levels dropped again during 2002/03. At that time the participation rate in that system

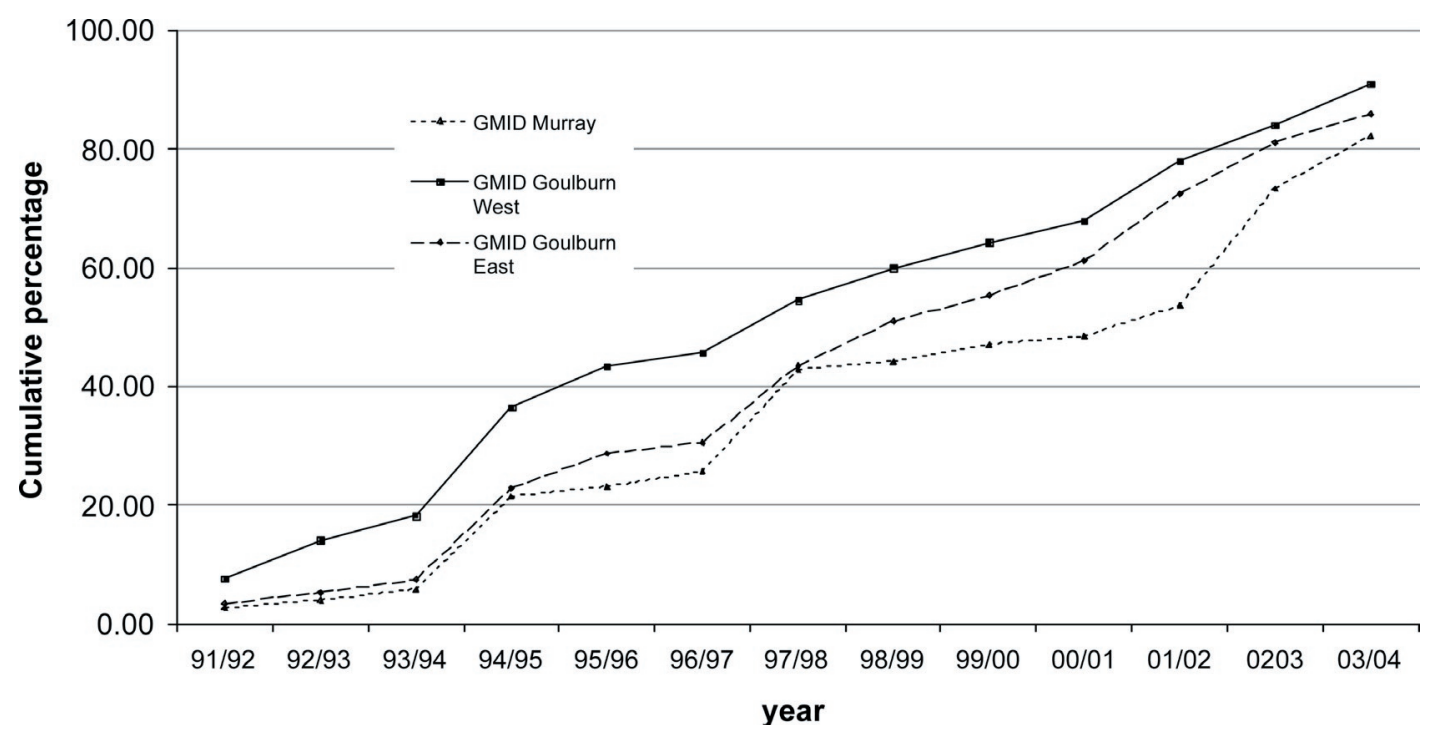

Figure 2. Accumulated percentage of farm businesses which have traded. 
reached the same level as in the Goulburn System, with $60 \%$ of all farm businesses participating in trading during that and the following season. Over the 13 year period (1991-2004) market participation has increased from less than $10 \%$ of farm businesses per year to about $60 \%$.

Figure 2 reveals the proportion of farm businesses that have participated in any kind of water trading from the beginning of trade to the end of each season. The figure reveals the same three jumps in market participation. It first increases from around $8 \%$ to $21 \%$ in 1994/95 when $13 \%$ of new farm businesses had their market debut. The next jump in the participation rate, to about $42 \%$, took place in $1997 / 98$ when allocations dropped in both systems (Table 1) with another 21\% of farm businesses entering water markets for the first time. Finally, the participation increased considerably, to $80-90 \%$, during $2002 / 03$ and $2003 / 04$, with about another $43 \%$ of farm businesses entering the market. At the present time, fewer than $15 \%$ of farm businesses have not participated in any kind of market activity. Water trading now seems to be an instrument that farmers use routinely to manage scarcity. In drawing this conclusion it has to be recalled that there is a substantial difference in the way the entitlement and allocation markets have been adopted by irrigators. Whereas around $60 \%$ of farm businesses are buying and/or selling allocations each year, only $2.5 \%$ are selling and $2 \%$ are buying entitlements.

\section{Conclusions}

In the Goulburn-Murray Irrigation District in Australia there is clear evidence that water markets have been widely adopted during the first 13 years of their operation. The major driver of the increase in activity and willingness to pay during this period has been scarcity due to a prolonged period of drought and policy changes. During this period, high value users have been willing to pay increasing prices for water relative to the prices paid for the major commodities produced. The allocation market has played an important role in enabling irrigators to manage scarcity by allowing high value water users with substantial capital investments in plantings, dairy herds and milking equipment, to buy water to retain their herds and to keep their permanent plantings alive. In this process, they compensated the low value producers selling their water by offering prices in excess of what these farmers could make from using it.
Once the region is out of this period of drought, further research should be conducted to establish the water price/commodity price relationship during periods of more normal supply.

During the worst drought years, $60 \%$ of all farm businesses were active in the market and almost a quarter of all the water used was purchased in the allocation market. There is, however, still widespread reluctance to adopt the use of entitlement markets due to uncertainty over the long-term security of entitlements. Initially, farmers preferred to buy water seasonally in the form of water allocations if they needed it. However, a couple of seasons with exceptionally low allocations caused allocation prices to reach unviable levels and at times it was difficult for high-value irrigators to secure enough water when they needed it. This caused increased activities in the entitlement market as more viable farmers sought to ease their reliance on seasonal purchases.

When new jurisdictions consider introducing markets it is important that the issue of resource availability is addressed first, and that the volume of water available for consumptive use is capped at that level. When introducing markets, it is also important to maximize market flexibility by allowing trading to take place within a large geographical area and between as many different user categories as possible, while respecting hydrological, environmental and social constraints of catchments.

\section{Acknowledgement}

This research is part of a larger project funded by the Australian Research Council and six industry partners: Murray-Darling Basin Commission, Department of Natural Resources in New South Wales; Department of Sustainability and Environment in Victoria, Goulburn-Murray Water, Department of Water, Land and Biodiversity Conservation in South Australia and UpMarket Software Services.

\section{References}

ACIL Tasman. 2003. Water Trading in Australia Current and Prospective Products. ACIL Tasman, Canberra.

Bjornlund, H. 2002. The socio-economic structure of irrigation communities - water markets and the ructural adjustment process. Rural Society 12: 123-145. 
Bjornlund, H. 2003a. Farmer participation in markets for temporary and permanent water in southeastern Australia. Agricultural Water Management 63: 57-76.

Bjornlund, H. 2003b. Efficient water market mechanisms to cope with water scarcity. The International Journal of Water Resources Development 19:553-567.

Bjornlund, H. 2004a. What impedes water markets? Water 31:47-51.

Bjornlund, H. 2004b. Formal and informal water markets - Drivers of sustainable rural communities? Water Resources Research 40, W09S07.

Bjornlund, H. 2004c. Water Markets, Water Rights and the Environment - What the Irrigation Community Tells Us, Victoria, New South Wales and South Australia. Industry Partner Report for an ARC SPIRT project. Adelaide, University of South Australia. For a copy contact henning.bjornlund@ unisa.edu.au

Bjornlund, H. and P. Rossini, P. 2005a. Fundamentals determining prices and activities in the market for temporary water. The International Journal of Water Resources Development 21:355-369.

Bjornlund, H. and P. Rossini. 2005b. Is investments in water entitlements a rational option? Australian Property Journal 38:464-472.
Bjornlund, H. and P. Rossini. 2006. An empirical analysis of factors driving outcomes in markets for permanent water - An Australian case study. Proceedings from the $12^{\text {th }}$ Annual Conference of the Pacific Rim Real Estate Society, Auckland, New Zealand, January. Available at www.business. unisa.edu.au/prres

Bjornlund, H. 2006a. Can water markets assist irrigators managing increased supply risk? Some Australian experiences. Water International 31: 221-232.

Bjornlund, H. 2006b. The Monitoring of, and reporting on, water trading within the GoulburnMurray Irrigation District, Industry Partner Report No. 2. ARC Linkage Grant 'Water Scarcity and Rural Social Hardship - can water markets alleviate the problems?'. Adelaide, University of South Australia. For a copy contact henning.bjorl und@unisa.edu.au

Brookshire, D.S., B. Colby, M. Ewers and P.T. Ganderston. 2004. Market prices for water in the semiarid West of the United States. Water Resources Research 40, W09S04.

Turall, H.N., T. Etchells, H.M.M. Malano, H.A. Wijedasa and P. Taylor. 2005. Water trading at the margin: The evolution of water markets in the Murray-Darling Basin. Water Resources Research 41, W07011. 